\title{
As cores em imagens de sensoriamento remoto
}

Helena K. Boscolo e Laercio Namikawa

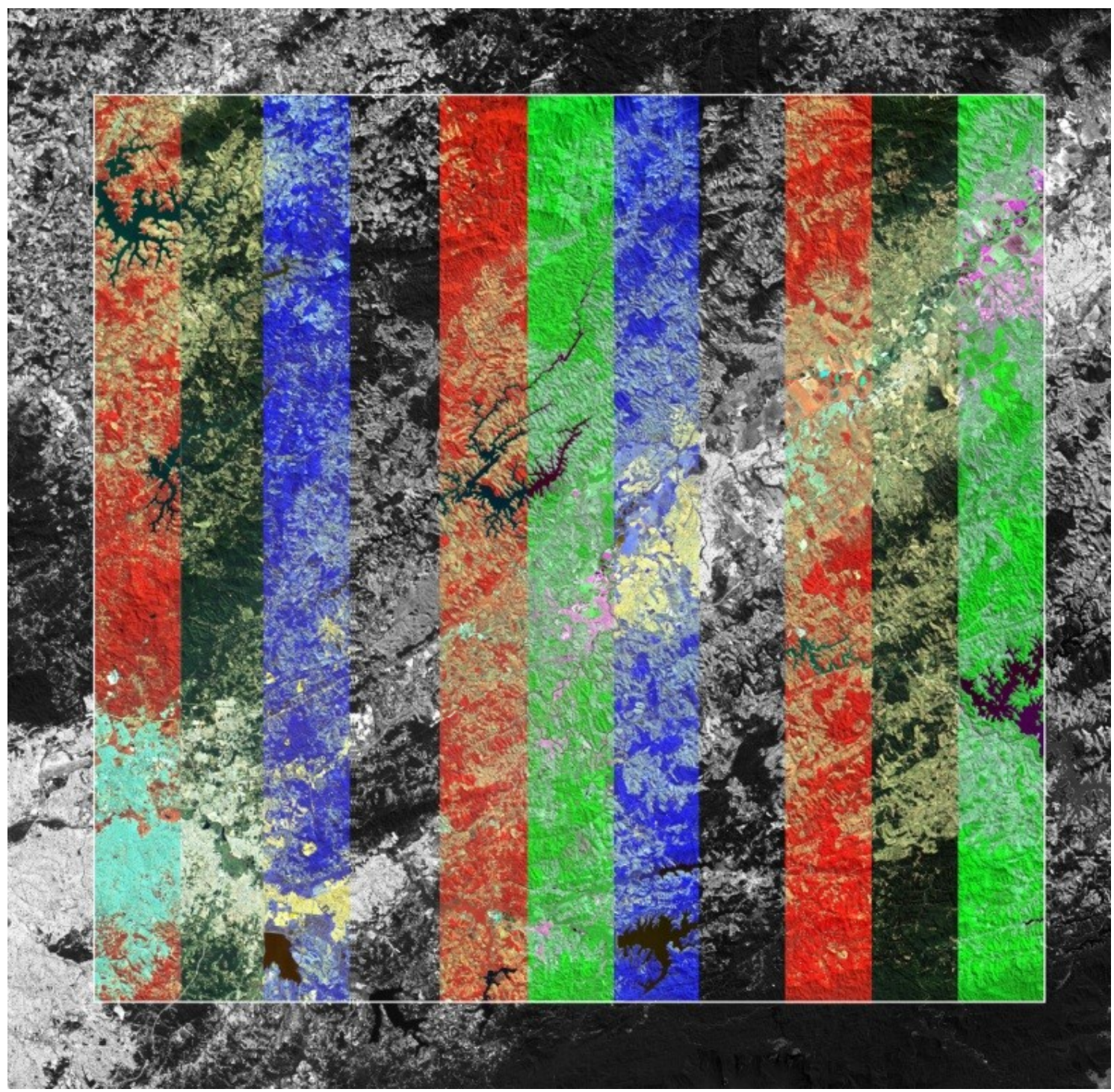

Legenda: Imagem ao fundo (Banda 7 em nível de cinza); Faixas representam as diferentes composições de bandas em RGB, na sequência: 8-6-5, 7-6-5, 5-6-8, 7-7-7, 8-6-5, 5-8-6, 5-6-8, 7-7-7, 8-6-5, 7-6-5 e 5-8-6. Na composição 8-6-5 a vegetação é representada pelos vermelhos; na 7-6-5, pelos verdes escuros; na 5-6-8, pelos azuis; na 7-7-7, pelos cinzas muito escuros; e na 5-8-6, pelos verdes.

Há um ressurgimento na arte e ciência da interpretação visual de imagens à medida que os sistemas digitais de sensoriamento remoto fornecem imagens mais aprimoradas.

Um dos elementos mais utilizados na interpretação visual de imagens em sensoriamento remoto é a cor. 
Uma imagem de sensoriamento remoto, por sua natureza digital, é constituída por um arranjo de elementos em forma de grade regular retangular. Cada célula desta grade (um pixel) é indexada por linha e coluna e representa uma área da superfície da Terra possuindo um determinado valor numérico (um número digital). O valor numérico corresponde sempre à média da intensidade da energia eletromagnética refletida, emitida ou retroespalhada pelos diferentes materiais presentes no pixel, e capturada pela célula do sensor localizado no satélite.

As cores no sensoriamento remoto são derivadas de uma composição de bandas do espectro de energia eletromagnético separadas por intervalos de comprimento de onda.

O olho humano é capaz de discernir cerca de 7 milhões de cores localizadas no espectro visível, mas somente cerca de 30 tons de cinza. Assim, uma composição colorida otimamente selecionada traduz a informação desejada disponível nas bandas para o olho humano da melhor forma possível. Uma única banda espectral é uma imagem em tons de cinza, enquanto a combinação de três bandas espectrais apresentada nos componentes básicos de cor aditiva (vermelho, verde e azul) forma uma imagem colorida. A imagem colorida permite visualizar a informação multiespectral, onde as bandas não são restritas ao espectro visível.

As bandas espectrais do sensor MUX do satélite sino-brasileiro CBERS-4 (imagem acima) apresentam as ondas eletromagnéticas nas faixas: 0,770 a 0,890 $\mu$ m (Banda 8, infravermelho-IR); 0,630 a 0,690 $\mu$ m (Banda 7, vermelha-R); 0,520 a 0,590 $\mu \mathrm{m}$ (Banda 6, verde-G); e 0,440 a 0,485 $\mu \mathrm{m}$ (Banda 5, azul-B). As faixas de ondas eletromagnéticas que representam a faixa visível do espectro eletromagnético deste sensor são as bandas espectrais $7(\mathrm{R}), 6(\mathrm{G})$ e $5(\mathrm{~B})$, equivalentes às cores percebidas pelo olho humano e cuja composição colorida em uma imagem de sensoriamento remoto é denominada composição cor verdadeira.

O sistema de cores primárias vermelho, verde e azul (RGB) é utilizado para visualização de imagens de sensoriamento remoto. Uma equação que define qualquer cor é representada pela soma das quantidades x, y e $\mathrm{z}$ de vermelho, verde e azul $(\mathrm{COR}=\mathrm{x} . \mathrm{R}+\mathrm{y} . \mathrm{G}+\mathrm{z} . \mathrm{B})$.

Na imagem acima do sensor MUX do satélite sino-brasileiro CBERS-4 as faixas coloridas representam as bandas 5, 6, 7 e 8 em diferentes composições RGB (veja legenda).

A substituição de uma banda que representa uma cor primária por uma banda espectral na faixa do infravermelho promove um destaque na cor, como visualizamos nas faixas coloridas da imagem acima.

Conheça mais imagens do satélite CBERS-4 na Galeria de Imagens da Coordenação de Observação da Terra/INPE. 


\section{Fontes consultadas:}

Crósta, A. P. 1992. Processamento Digital de Imagens de Sensoriamento Remoto, Ed. UNICAMP, 170 p.

Jensen, J. R. 2011. Sensoriamento Remoto do Ambiente: uma perspectiva em recursos terretres, Ed. Parêntese, 598 p. 